\title{
A Case Study of Concept Development of Service Quality Measurement System for Mobile Telecom Service Encounter in Thailand
}

\author{
Teerapon Tanomsakyut \\ Technopreneurship and Innovation \\ Management Program, \\ Chulalongkorn University, \\ Phayathai road, Pathumwan, \\ Bangkok 10330, Thailand
}

\author{
Natcha Thawesaengskulthai \\ Ph.D \\ Department of Industrial Engineering \\ Chulalongkorn University, \\ Phayathai road, Pathumwan, \\ Bangkok 10330, Thailand
}

\author{
Pongpun Anuntavoranich \\ Ph.D \\ Technopreneurship and Innovation \\ Management Program \\ Chulalongkorn University, \\ Phayathai road, Pathumwan, \\ Bangkok 10330, Thailand
}

\begin{abstract}
In this paper, we describe a case study of a concept development process of service quality measurement system for mobile telecom service encounter (SQM-ME system) in two main phase, which are product planning and concept development phase. The SQM-ME begins with market opportunity exploration. The identification of the user and buyer is concerned mainly with functional design as user requirements. Next, a systematic approach of product strategy development helps the developers to achieve we utilized strategic canvas, which is a critical diagnostic and action to create value innovation and selects appropriate technologies to meet customer needs. The planning activities mainly based on the assessment of secondary data. In the concept development phase, the idea generation session was employed and utilizes the concept of idea screening based on technology and market readiness. The result shows that the software as a service (SaaS) on cloud computing was selected for SQM-ME system and integrate with other technologies such as SMS technology, website design, queuing system, and mobile application. This paper shows the opportunity for future research in system and detail design for SQM-ME system.
\end{abstract}

\section{General Terms}

Information Management System, New Software Development

\section{Keywords}

Service Quality Measurement, Cloud Computing Software, Service Measurement System, Concept Development

\section{INTRODUCTION}

The mobile telecom industry plays an important role in Thailand economy by creating employment, investment on infrastructure and communication system that allows Thai consumers to gain benefit from increased mobile communication service. The mobile telecom industry contributes an economic value equal to 4.7 per cent of GDP in Thailand. The industry is also a significant source of employment, directly and indirectly employing 150,000 in Thailand [1]. To response the sophisticated environment, service quality (SQ) seems to be a key driver of business success especially in the market saturation stage in Thailand [2]. Li [3] suggested that a firm cannot gain the competitive advantage in today's business environment without delivering high quality service. Lewis and Entwistle [4] stated that all organizations needed to focus on service encounter because it is the critical element in overall performance and evaluation of service experience of customers. Therefore, there is an opportunity to develop a standard instrument to measure SQ in mobile telecom's service encounter. The development of new product typically contains many stages, but this study mainly focuses on concept development phase. This study contributes to the growing theory of SQ measurement by explaining the concept development of innovative information management system that designed to fit in service encounter in Thai mobile telecom industry. In addition, a number of technologies will be explored and developed for service encounter in order to measure the level of SQ effectively. The integration of technologies and the SQ measurement framework will provide a great contribution to management to control the level of SQ as an effective indicator.

\section{SERVICE QUALITY MEASUREMENT}

There are many differences between product quality and service quality. Parasuraman, Zeithaml and Berry [5] define the service quality as the differences between customers' expectation and their perception of actual service performance. Service quality is not only the outcome, but it also involves the service delivery process. Berry [6] stated that intangible in service is problematic and lead to the difficulty in measuring comparing with manufacturing which has the uniform quality. Over a decade, various SQM instruments were developed in order to find the complete solution for measuring SQ in particular service area. SERVQUAL instrument by Parasuraman [7] has been the most widely used SQM but it has also been criticized by many authors. Thus various SQM models have been proposed by many researchers. Recently, the research theme has been paid attention to the development of SQM model to fit the specific service context. Figure 1 shows the detail of SQM model that was developed by Tanomsakyut and Thawesaengskulthai [8] in order to measure service quality of mobile telecom service shops. The traditional method of measuring SQ is customer survey by comparing customer expectation and customer perception. However, this model highlights another aspect of measuring SQ, which is the important of management perception on SQ by using the tangible result that was collected by the system and compared with corporate SQ policy. Thus, the effective information system 
is required. In addition, the system should collect the required data properly with user-friendly interface. The benefit of SQM system is to assist management to monitor SQ indicator real time and take proactive initiatives for SQ improvement. Consequently, there is an opportunity for software developer to create the system that fit to SQM-ME model and collect the tangible data. The result will be compared with corporate policy and represent the information to executives in the right time.

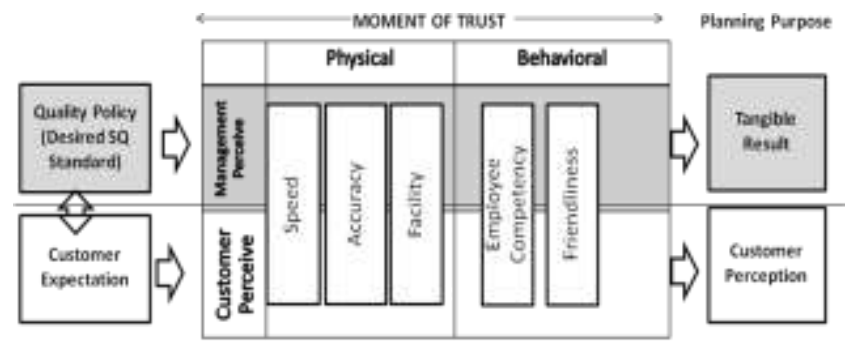

Evecution Purpose

Figure1 SQM-ME Model

\section{SQM SYSTEM DEVELOPMENT}

\subsection{New Product Development Process}

The new product development (NPD) process consists of six phases based on Ulrich and Eppinger [9], (see Figure 2). The process begins with a planning phase, which is the link to advanced research, current market situation and selected technology, which is cloud computing. The strategic canvas process was employed. The output of the planning phase is the project's mission statement, which is the input required to begin the concept development phase and which serves as a guide to the development team. The first phase is concept development, which utilizes field observation process. It presents a description about current practice in mobile service shops. Six mobile service shops in Thailand were selected. By doing this observation approach, an in-depth study was also perform in order to get the specific requirements and all constraints for SQM-ME system. The system level design was implemented by selecting the technologies and designs the functional detail.

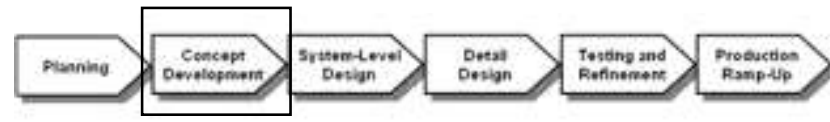

Figure2. NPD Process

In the detail design phase, before going further with cloud computing technology, it is essential to know the basic characteristic of cloud computing. Therefore, the result of literature reviews related to cloud computing was explored and investigated. User interface was designed in this phase. Finally, the SQM system was tested by prospect users. However, this paper focuses only on planning and concept development.

\subsection{SQM Development Workshops}

New product development (NPD) process involves several groups of people that have to participate in the project in different timeframe. It requires more specialized skill such as information technology, customer interface and concept generation. Table 3.6 shows the detail of session name and the workshop methodology for developing SQM-ME system.

\begin{tabular}{|c|c|c|c|}
\hline Session Name & $\begin{array}{c}\text { No. of } \\
\text { Participants }\end{array}$ & Time & $\begin{array}{c}\text { Workshop } \\
\text { Detail }\end{array}$ \\
\hline $\begin{array}{l}\text { Strategic } \\
\text { Planning } \\
\text { Session } \\
\text { (Planning phase) }\end{array}$ & $\begin{array}{c}6 \\
(\mathrm{NPD} \\
\text { Team) }\end{array}$ & $\begin{array}{c}14.00-16.00 \\
15 \text { Febuary } \\
2010\end{array}$ & Brainstorming \\
\hline $\begin{array}{l}\text { Process Mapping } \\
\text { Session (Concept } \\
\text { Development) }\end{array}$ & $\begin{array}{c}15 \\
\text { (Process } \\
\text { Owners) }\end{array}$ & $\begin{array}{c}9.00-16.00 \\
25-26 \\
\text { March } \\
2010\end{array}$ & $\begin{array}{l}\text { In depth } \\
\text { Interview }\end{array}$ \\
\hline $\begin{array}{l}\text { Customer Need } \\
\text { Session (Concept } \\
\text { Development) }\end{array}$ & $\begin{array}{c}20 \\
\text { (User } \\
\text { group) }\end{array}$ & $\begin{array}{c}14.00-16.00 \\
12 \text { April } \\
2010\end{array}$ & Focus group \\
\hline $\begin{array}{l}\text { Concept } \\
\text { Development } \\
\text { Session }\end{array}$ & $\begin{array}{c}6 \\
(\mathrm{NPD} \\
\text { Team) }\end{array}$ & $\begin{array}{l}9.00-16.00 \\
25 \text { April } \\
2010\end{array}$ & $\begin{array}{l}\text { Brainstorming } \\
\text { (Idea } \\
\text { Generation }+ \\
\text { Idea Screening) }\end{array}$ \\
\hline Monthly Meeting & $\begin{array}{c}6 \\
(\mathrm{NPD} \\
\text { Team) }\end{array}$ & $\begin{array}{l}\text { 14.00-16.00 } \\
\text { Monthly }\end{array}$ & Update Status \\
\hline
\end{tabular}

\section{RESULTS}

First of all, list of technologies were proposed by development teams. The choice of number of technologies involves the tradeoff between two factors, which are market readiness and technology readiness. At the beginning, strategic planning session was conducted by executives and quality managers in order to gain the key business goals. Various available systems were compared and find out the competitive gap for new system. The consensus from strategic planning session was described in the next topic.

\subsection{Key Business Goals}

\subsubsection{Cost Leadership}

SQM-ME eliminates the need to purchase hardware and software that must be installed, configured, upgraded and maintained internally. The on-demand subscription model bundles all of those costs into periodic payments that enable customers to avoid the upfront expenditures for technology purchases along with the associated investments in IT support staff.

\subsubsection{Easy to install and maintain}

SQM-ME suit on-cloud architectures allow an organization to go from technology selection to deployment as quickly as their data can be made available. In addition, lengthy projects are no longer necessary to upgrade SQM-ME software, since that is part of cloud computing service. 


\subsubsection{Ease of use and User friendly}

The existing traditional SQ measurement in the market is complex and difficult to use. SQM-ME requires the ease of use in the view of customers. To determine "ease of use," first understand the customer and user needs. To understand their needs, conduct research, iterate designs for validation, and evaluate the design for ease-of-use.

\subsubsection{Real time monitoring}

A real-time software solution provides a visual representation of business data. Flexible displays help managers quickly highlight problem areas. Automatic real-time updates keep business moving forward.

\subsubsection{Automatic Distribute Data}

Easily distribute important information with e-mail and data export options.

\subsubsection{Dynamic Filtering and Search}

Dynamic filtering and search features allow users to quickly locate specific data on the fly without changing their display.

\subsection{Process Mapping}

Process mapping is one of the oldest, simplest and most valuable techniques for streamlining work [10]. Process mapping refers to activities involved in defining exactly what a business entity does. The process mapping approach of mobile service shop was implemented in a model case, which is Thai mobile shop. The process mapping can be considered as the simplest ways to analyze current situation of mobile shop visually as well as to detail other parts of a process or an entire process. The key processes were grouped into two categories, which are core processes and supporting processes. The result of process mapping was identified by gathering quality data via in-depth interview.

The key activities of service delivery in mobile shop contain six core processes, which are greeting process, selling product, queuing process, bill payment, after-sale service, and satisfaction gathering process. There are four main supporting processes, which are shop opening \& preparation, stock management, process backend and customer compliant management.
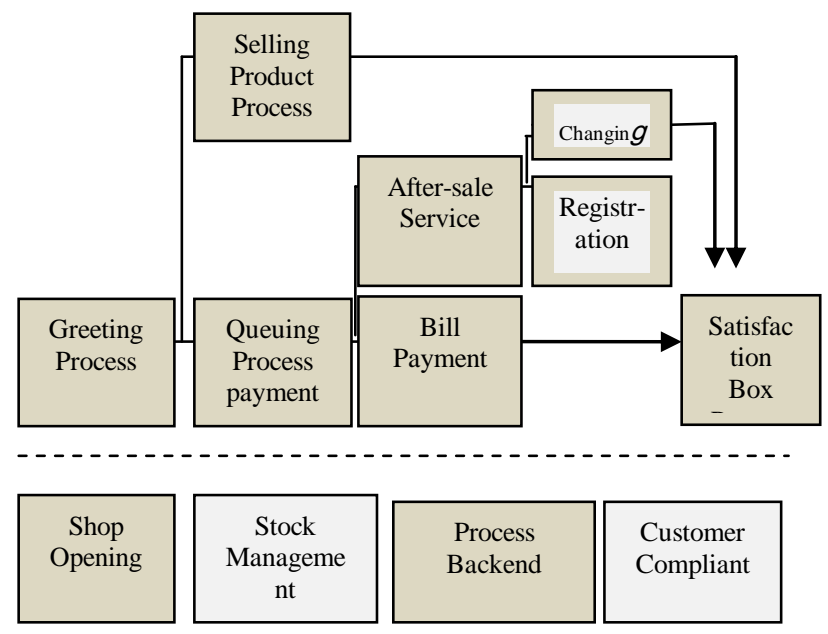

Figure4. Core Processes and Supporting Processes

\subsection{Concept Development}

SQM-ME system was designed to move away from traditional product. It is not a single tangible product but contains the total utility created through the customer's experience of using service quality measurement system. So, the need of customers will be the requirement for the concept development session.

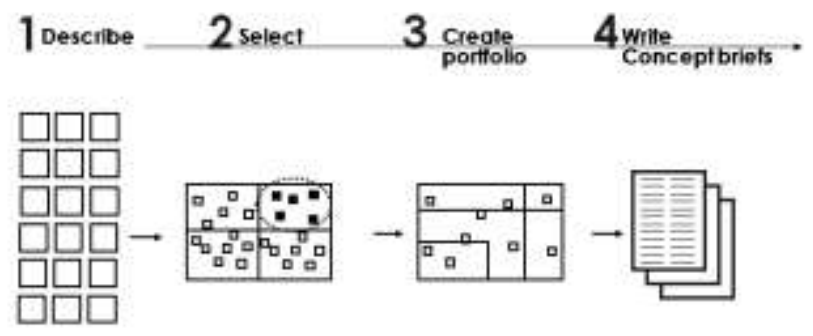

Figure5. Concept Development

Ideas for product development come from many sources, both internal and external. The strategic planning session utilize brainstorming method to generate ideas. Firstly, the concept development session conducted sitting around the table of 6 people. The project leader provides the information about customer expectations and market background. Teams were granted a relatively high level of autonomy and independence in this program. The idea generation session was conducted in four rounds. The first round did not allow the members to have any face-to-face conversation. They had to provide input as many ideas as possible. The ideas were written into the post it papers. Secondly, the list of ideas was classified into various groups. Some ideas were similar, so it was collected into the same group. The list of ideas can be summarized as table 2:

Table2. Idea Generation

\begin{tabular}{|c|c|c|}
\hline 1. Cloud computing & 2. Pay per use & $\begin{array}{l}\text { 3. Access via } \\
\text { mobile }\end{array}$ \\
\hline 4. Online Survey & 5. Alert System & $\begin{array}{l}\text { 6elf software } \\
\text { management }\end{array}$ \\
\hline 7. Graphic Report & 8. Innovation Score & $\begin{array}{l}\text { 9. Compare the } \\
\text { result with } \\
\text { history }\end{array}$ \\
\hline 10. Satisfaction Box & $\begin{array}{l}\text { 11. Voice } \\
\text { Recognition }\end{array}$ & $\begin{array}{l}\text { 12. Face } \\
\text { Recognition }\end{array}$ \\
\hline 13. Text to speech & $\begin{array}{l}\text { 14. Automatic } \\
\text { system }\end{array}$ & $\begin{array}{l}\text { 15. Telephone } \\
\text { Survey }\end{array}$ \\
\hline $\begin{array}{l}\text { 16. Artificial } \\
\text { Intelligence }\end{array}$ & $\begin{array}{l}\text { 17. Upgrade from } \\
\text { Center }\end{array}$ & $\begin{array}{l}\text { 18. English/Thai } \\
\text { language }\end{array}$ \\
\hline 19. Forecast function & 20. SQ SMS Alert & 21. Queuing Alert \\
\hline $\begin{array}{l}\text { 22. SQ Improvement } \\
\text { Tracking }\end{array}$ & $\begin{array}{l}\text { 23. Daily Report } \\
\text { Setting }\end{array}$ & $\begin{array}{l}\text { 24. Interface } \\
\text { Customization }\end{array}$ \\
\hline
\end{tabular}


After the lists of ideas were classified, the data was filled in the idea screening grid by comparing value to business and value to customers. The third round using the consensus of product development team.

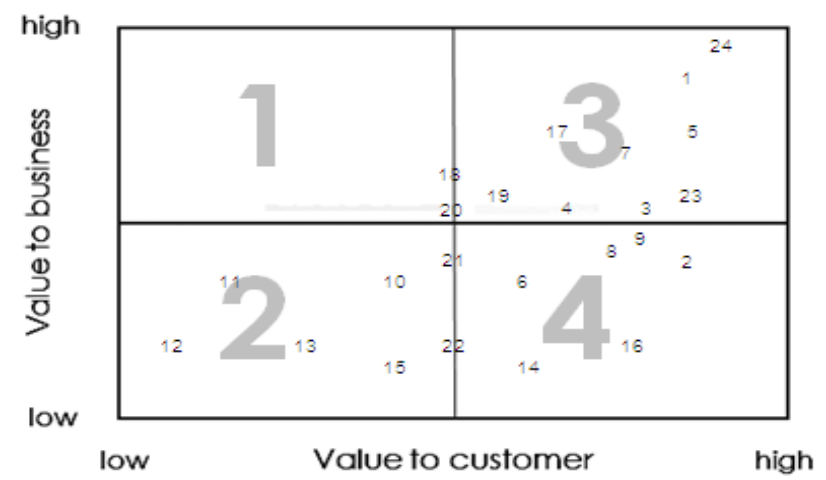

Figure6. Idea Screening

According to figure 6 , the development team selected all ideas in quadrant three, which is highest value to business and customers. The selected ideas consists of software cloud computing technology, access via mobile, online survey, alert system, graphic report, upgrade from center, Thai-eng language, forecast function, SMS alert, daily report setting and interface customization. Finally, the selected technology will be plotted into idea portfolio matrix in order to understand the selected technology and the readiness of market.

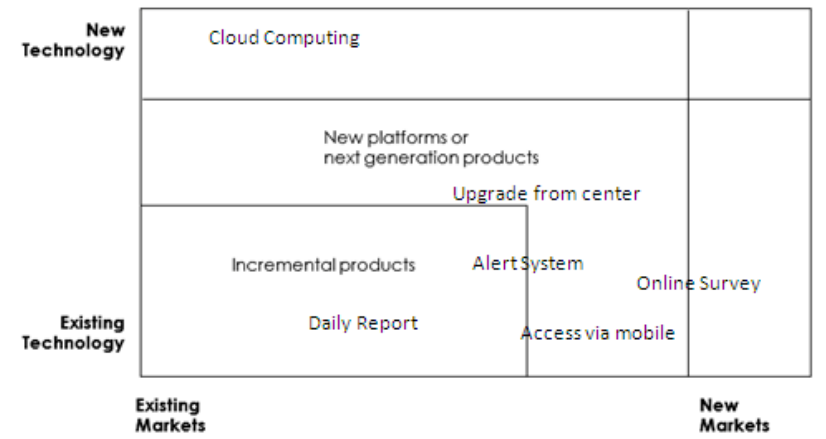

Figure7. Idea Portfolio

\section{SQM SYSTEM CONCEPT SUMMARY 5.1 Cloud Computing Technology}

When talking about a cloud computing system in SQM-ME architecture, it's helpful to divide it into three sections, which are the infrastructure, SaaS on cloud and the front end reporting system. They connect to each other through a network, usually the Internet. The reporting system is the side the computer user, or client, sees, which can be several channel such as website, iPad and mobile phone. The SaaS section is the core engine of SQM-ME system that calculates the input by SQM-ME engine, the process of data collection and security module. In addition, the alert system will be started when the output is in the specific criteria. The process backend is explained by infrastructure section, which consists of cloud server, cloud storage and resource pool. The users can monitor usage via the management dashboard.
The value curve is the basic component of the strategy canvas. It is a graphic depiction of a company's relative performance across its industry's factors of competition. Figure 3 illustrates the strategy canvas of the SaaS comparing with traditional software and traditional customer survey. The result shows that the traditional customer survey is the common method of measuring SQ but the investment cost is high comparing to other methods. Traditional software is usually designed for specific requirement. The investment cost for developing SQM software is high. Customer has to manage the program themselves. The software requires various specifications. Customer has to pay for upgrade fee and version control.
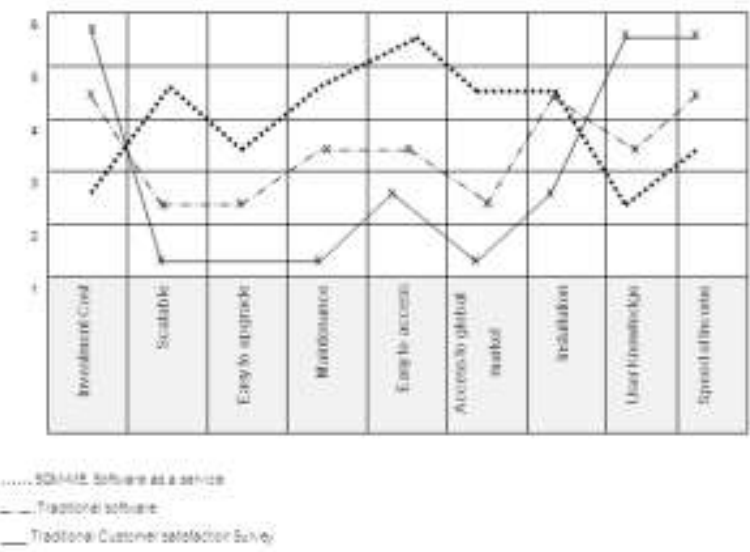

Figure3. Strategic Canvas

The result can be summarized that SQM-ME system on cloud computing has a good opportunity for commercialization. The initial investment is not high compared with others. In addition, this system can expand to international market because the ability of SaaS allows customer from everywhere to access the system via internet.

\subsection{SQM Report Delivery System}

In the report delivery system, customer can choose the specific date and branches of mobile service shops. SQM-ME can be able to produce high quality business reports that will be in userfriendly format. SQM-ME is adept at quickly organizing massive amounts of operational data into hierarchical categories that are fundamental to production operations. The reports feature easy page and section navigation, including labels, headers, footer and page break logic. The report delivery portal shows the criteria that user can easily select from the check box. Service quality can be shown by branches or by employees. The result can be showed in various dimensions such as the comparison between the current performance and the past.

\subsection{Reporting via Mobile Phone}

SQM system is located on cloud computing, so the system can access via website. Consequently, all reporting system can be accessed by using mobile phone to access the internet. The benefit of mobile access includes speed up executive decision making, Improve daily customer services, Increase operational productivity and streamlines service delivery processes, mitigate risks in mobile service shops management. 


\subsection{SMS Alert}

SQM-ME system can send alerts if the data meet the pre-defined criteria while processing processes or in the background processing for a service delivery process chain. The alert is sent to the user who scheduled the process chain. The user can assign additional recipients by assigning roles or specifying individual users in alert category maintenance.

\section{CONCEPT TESTING}

The initial test for most new products involves getting customer reactions to the product concept in order to get an initial notion of the commercial prospects of a concept.

Table3. Idea Generation

\begin{tabular}{|c|c|c|c|}
\hline $\begin{array}{c}\text { Attributes/Char } \\
\text { acteristics }\end{array}$ & $\begin{array}{c}\text { Ma } \\
\text { xim } \\
\text { um }\end{array}$ & Score & Description \\
\hline $\begin{array}{l}\text { A. Functionality, } \\
\text { scalability, and } \\
\text { adaptability, } \\
\text { emphasizing } \\
\text { client interaction } \\
\text { (Software } \\
\text { Applications } \\
\text { only) }\end{array}$ & 5 & 4.2 & $\begin{array}{l}\text { Software Applications } \\
\text { designed to fulfill business } \\
\text { requirements and } \\
\text { maximize the efficiency } \\
\text { and effectiveness of } \\
\text { business functions with the } \\
\text { ability to scale and adapt } \\
\text { as business requirements } \\
\text { change. }\end{array}$ \\
\hline $\begin{array}{l}\text { B. Platform } \\
\text { independence } \\
\text { and use of cloud } \\
\text { computing } \\
\text { technologies }\end{array}$ & 5 & 4.6 & $\begin{array}{l}\text { Cloud computing platform } \\
\text { enable users to use with } \\
\text { easy implementation, } \\
\text { programming languages, } \\
\text { middleware, development } \\
\text { tools, databases, utilities, } \\
\text { etc. }\end{array}$ \\
\hline $\begin{array}{l}\text { C. Exchange of } \\
\text { information, } \\
\text { integration with } \\
\text { other software }\end{array}$ & 5 & 4.7 & $\begin{array}{l}\text { Utilizes common, standard } \\
\text { interfaces and/or } \\
\text { middleware having the } \\
\text { ability to interoperate and } \\
\text { integrate with other } \\
\text { software without requiring } \\
\text { custom programming or } \\
\text { intermediate, interface- } \\
\text { specific applications. }\end{array}$ \\
\hline $\begin{array}{l}\text { D. Ability to } \\
\text { maximize (take } \\
\text { full advantage of) } \\
\text { Target Network, } \\
\text { Security, and } \\
\text { Platform } \\
\text { Architectures }\end{array}$ & 5 & 4.1 & $\begin{array}{l}\text { Has the capability to } \\
\text { conform to, and adhere to, } \\
\text { the standards and best } \\
\text { practices delineated in the } \\
\text { other domain architectures } \\
\text { without requiring } \\
\text { substantial modifications. }\end{array}$ \\
\hline Rating Score & 20 & 17.6 & \\
\hline
\end{tabular}

We present 20 customers with a written statement of the product idea and then record their reactions.

\section{CONCLUSIONS}

This paper contains a case study of a concept development process for new service quality measurement system for mobile telecom industry in Thailand. This paper describes the processes, and results from concept development phase in SQM-ME development project. The challenge for development team is that SQM-ME systems need to deliver the right information of mobile service shops to the right users at right time. Since the source information can potentially come from many different and nonintegrated sources, data has to be processed in SQM-ME on cloud computing before it is effectively delivered to the end user. There are many data flows existing in any business intelligence system. In the concept development phase, the development team begins with idea generation by conducted in four rounds. The first round did not allow the members to have any face-to-face conversation. They had to provide input as many ideas as possible. The ideas were written into the post it papers. Secondly, after the lists of ideas were classified, the data was filled in the idea screening grid by comparing value to business and value to customers. The selected ideas consists of software cloud computing technology, access via mobile, online survey, alert system, graphic report, upgrade from center, Thai-eng language, forecast function, SMS alert, daily report setting and interface customization. Finally, the selected technology will be plotted into idea portfolio matrix. Finally, results from concept development will be delivered to system level design.

\section{REFERENCES}

[1] Aske, M. 2008. Mobile Industry Powers Emerging Economies. Telenor Group

[2] Johnson, W.C., Service quality in the Thai telecommunication industry: a tool for achieving a sustainable competitive advantage, Sripatum University.

[3] Churchill, G. and Surprenant, C. 1982, "An Investigation into the Determinants of Customer Satisfaction, Journal of Marketing Research, Vol. 19, November, pp. 491-504.

[4] Lewis, B. and Entwistle, T. 1990. Managing the Service Encounter: A Focus on the Employee,International Journal of Service Industry Management, Vol. 1 No. 3, pp. 41-52.

[5] Parasuraman, A., Zeithaml, V. and Berry, L. 1985. A Conceptual Model of Service Quality andits Implications for Future Research. Journal of Marketing, Vol. 49, Fall, pp. 41-50

[6] Berry, L. 1984. The Employee as Customer, in Services Marketing, Lovelock, C. (Ed.), American Marketing Association, Chicago, IL, pp. 242.

[7] Carlzon, J. (1987), Moments of Truth, Harper and Row, New York, NY

[8] Tanomsakyut and Thawesaengskulthai. 2010. A Delphi Study of Service quality measurement for mobile telecom industry, Cottbus, Germany

[9] Ulrich K.T. and Eppinger S.D. 1995. Product Design and Development, 4th edition, Irwin McGraw-Hill

[10] Aldowaisan, T.A. and Gaafar, L.K.1999. Business process reengineering: an approach for process mapping. Mechanical and Industrial Engineering Department. 